\title{
IMPROVING MARKET ACCESS: THE ROLE OF AUCTIONS IN CONVERTING TARIFF-RATE QUOTAS INTO SINGLE TARIFFS
}

\author{
Robert Joerin
}

Address: Robert Joerin

Swiss Federal Institute of Technology ETH, Agricultural Economics, Sonneggstrasse 33, 8092 Zurich, Switzerland, Tel: + 4144 632 5399; Fax: + 41446321086

Corresponding author: joerin@ethz.ch

\begin{abstract}
This paper analyses the conversion of TRQs into single tariffs under perfect and imperfect competition. Based on experiences from Switzerland, auctions allow the determination of the equivalent tariffs. Results from auctions of TRQs of dried meat products under perfect competition show that the observed auction prices would lead to tariffs which are below the equivalent tariffs. Hence, if the 'new tariffs' would be determined through auctions, market access would be improved, but also farm prices would lower. However, under imperfect competition, based on Bhagwati's theorem of the non-equivalence of tariffs and quotas, market access could be improved by converting TRQs into single tariffs even if farm prices are held constant. In order to ensure that auctions are competitive and collusion among bidders is prevented, the 'variable supply' auction format which resists collusion needs to be adopted in the event of high buyer's concentration. Despite the various benefits of auctions, quota holders' persisting rentseeking behaviour hinders that auctions are mainstreamed in allocating TRQs.
\end{abstract}

Keywords: tariff-rate quotas, imperfect competition, auctions, WTO

JEL: Q17, F13, D44

\section{INTRODUCTION}

Tariff-Rate Quotas (TRQs) are an essential problem in relation to market access for agricultural products. TRQs stand in contradiction to the principle of the GATT 1947, according to which all quantitative restrictions in international trade should be eliminated. This principle resulted from the experience of crude protectionism during the 1930s when quotas were used as a dominant instrument in trade policy ('managed trade'). After World War II, most import quotas of non-agricultural goods were eliminated. Furthermore, after several rounds of negotiations, tariffs were reduced significantly and led to a moderate level of protection for non-agricultural goods. Yet, in agricultural trade, which was for the first time included in multilateral trade negotiations during the Uruguay Round (1986-1994), import quotas were neither eliminated nor phased out, but replaced by TRQs. As most of the out-of quota tariffs are prohibitive, TRQs have a restrictive effect on trade similar to that of the previous quotas. It is one of the oldest insights that quantitative restrictions such as import quotas aggravate market power in protected markets. Bhagwati (1965) demonstrated that quotas create more market power than tariffs and therefore, the change from quotas to tariffs is welfare improving. Under imperfect competition, tariffs and quotas do not have identical effects on market access.

In order to compare the different effects, first a simple model of perfect competition is presented. This is followed by analysing the effects on market access under imperfect conditions when changing from TRQs to single tariffs. The core problem of replacing TRQs with single tariffs is linked to what procedure should be used to determine the new equivalent tariffs. One of the first approach to auction quotas and to use the realised auction prices for setting the equivalent tariff was conceptualised by Bergsten et al. (1987). In this context, however, the danger of collusion among bidders could become a serious problem. Therefore, the design of an anticollusive auction mechanism ('variable supply') proposed by Lengwiler (1999) is highlighted. In this context, the experience of auctioning TRQs in recent time (2007-12) in Switzerland is of key interest.

\section{TARIFF-RATE QUOTAS AND SINGLE TARIFFS}

\section{Tariff-rate quotas and single tariffs: Analysis under perfect competition}

The economic interpretation of a TRQ is shown in Figure 1: thereby, both tariffs, the in-quota tariff and the out-of quota tariff and the quota $\mathrm{Q}^{*}$ build the staircase-shaped import supply function (ES). The domestic price is supported at the level of the intersection of the import demand function (ED) and the ES. Following Abbott and Paarlberg (1998) and Skully (2001), three cases can be distinguished:

A: The ED intersects the ES in the lower branch of the in-quota tariff. The TRQ is not binding, which results in a quota under-fill. The in-quota tariff determines the import quantity $\mathrm{Q}_{\mathrm{A}}$ and not the quota $\mathrm{Q}^{*}$. In order to improve the market access (higher fill-rate), 
the in-quota tariffs need to be reduced. This results in lower farm prices.

$\mathrm{B}$ : The ED intersects the ES in the upper branch of the out-of quota tariff. The TRQ is not binding anymore and out-of quota imports are generated (quota fill above $100 \%$ ). Similar to case A, the out-of-quota tariff determines the import quantity $\mathrm{Q}_{\mathrm{B}}$ and not the quota $\mathrm{Q}^{*}$. Like in case $\mathrm{A}$, reducing the out-of quota tariffs leads to higher import quantities and lower farm prices. Furthermore, in both cases the quota $\mathrm{Q}^{*}$ has no impact on the determination of the import quantity. Thus, the TRQs could be eliminated in cases A and B.

$\mathrm{C}$ : The ED intersects the ES at a point where the latter is vertical. This vertical section of the import supply function can be considered as the non-tariff element of the TRQ. The TRQ is binding and the quota fill rate is $100 \%$. The domestic price $\mathrm{P}_{\mathrm{C}}$ is supported by the quota $\mathrm{Q}^{*}$ and not by the tariffs. If the out-of quota tariff is prohibitively high, the TRQ has the same impact as the previous quotas. A reduction of out-of quota tariffs, therefore, does not lead automatically to higher imports, like in cases A and B. The larger the gap is between the in-quota and out-of quota tariff, the lower is the impact of reducing tariffs. This 'tariff gap' can be substantial: for OECD countries in-quota tariffs on agricultural products average 36\% while average out-of quota tariffs are $120 \%$ (WTO, 2001) ${ }^{1}$. The higher the tariff gap is, the bigger is the difference $\mathrm{P}_{\mathrm{B}}-\mathrm{P}_{\mathrm{C}}$, which is known as 'water in the tariffs' (Boughner, et al. 2000).

One may argue that the market access could also be increased through a quota expansion. However, this is fundamentally different compared to reducing tariffs, as instead of defining tariffs quotas are set. As a result, the politics of 'managed trade' is continued and the problematic non-tariff element persists. This, however, cannot be the goal of a substantial liberalisation of agricultural trade policy. Abbott (2002, p. 128), therefore, considers TRQs as a "failed market access instrument". He further argues that "this instrument is counter to the longstanding GATT-WTO tradition of first converting quotas and other non-tariff barriers to tariffs and then reducing those tariffs over time”. For case C, this means the following: the price $\mathrm{P}_{C}$ can be achieved through a tariff at the extent of $\mathrm{P}_{\mathrm{C}}-\mathrm{P}_{\mathrm{W}}$ which can be considered as an 'equivalent tariff'. At this first step, from TRQs to single tariffs, the import quantity $\mathrm{Q}^{*}$ and the farm price $\mathrm{P}_{C}$ remain the same. Once this first step is accomplished, the tariffs can be reduced. Hence, the question is how to find the equivalent tariff. Later in this paper, it is shown which role auctions could play in this process. At this point, however, another aspect about prohibitively high out-of quota tariffs emerges: border protection may weaken the intensity of competition on domestic markets. Therefore, it cannot be assumed anymore that there is perfect competition.

\footnotetext{
${ }^{1}$ These tariffs correspond to the level after the implementation period of the Uruguay Round. Until today, they remain high because no agreement could be found on tariff reduction during the Doha Round.
}

Trade distorting effects of TRQs: Analysis under imperfect competition

The context of protection and competition on domestic markets goes back to Adam Smith (1811, p. 316): ”By restraining, either by high duties, or by absolute prohibitions...the monopoly of the home market is more or less secured to the domestic industry...” Due to this old insight an approach was developed to show how trade distortions are caused under imperfect competition. In order to analyse the effects of quotas and tariffs, it is assumed that high out-of quota tariffs prohibit out-of quota imports ('pure quota'). ${ }^{2}$ Hence, a simple market structure is suggested (Figure 2): a dominant firm buys products from farmers and sells them to consumers. This represents the extreme case of imperfect competition where the dominant firm exerts market power on the domestic market. In order to compare the effects of quotas and tariffs on market access, a certain quantity $\mathrm{Q}^{*}$ for the import quota is fixed and the demand for domestic products is derived $\mathrm{D}_{1}=\mathrm{D}_{0}-\mathrm{Q}^{*}$ (Helpman, Krugman, 1992, p. 31).

$\mathrm{D}_{1}$ runs parallel to $\mathrm{D}_{0}$ until the interception point on the vertical axis because the out-of quota tariff is prohibitively high. Therefore, $\mathrm{D}_{1}$ is the relevant demand for the monopolist and S represents the farmers' supply. In the absence of any competition, the dominant firm reaches the maximum profit where the Marginal Revenue (MR) is equal to the Marginal Cost (MC); it is the equilibrium $\mathrm{G}^{\mathrm{M}}$. The wedge between the price farmers receive $\left(\mathrm{w}^{\mathrm{M}}\right)$ and the price consumers have to pay $\left(\mathrm{p}^{\mathrm{M}}\right)$ indicates the distortion caused by the absence of competition. ${ }^{3}$ As a consequence, market power generates disadvantages for both farmers and consumers. This is the result of quota protection under imperfect competition. Alternatively, the price $\mathrm{w}^{\mathrm{M}}$ could be realised by raising an equivalent tariff $\mathrm{t}^{\mathrm{eq}}$. Using tariffs eliminates market power because the dominant firm is not able anymore to set prices above $\mathrm{p}_{\mathrm{w}}+\mathrm{t}^{\mathrm{eq}}$. Consequently, it becomes possible to import the quantity $\mathrm{M}^{\mathrm{POT}}$ which is larger than the quota $\mathrm{Q}^{*}{ }^{4}$

Whenever imperfect competition occurs, the change from TRQs to single tariffs improves market access, holding farm prices constant. This was demonstrated by Bhagwati (1965) in his seminal article "On the equivalence of tariffs and quotas". Put differently, improvements in market access can be reached by eliminating TRQs and by setting equivalent tariffs.

\footnotetext{
${ }^{2}$ It is assumed that the in-quota tariff is "minimal”, that is, equal to zero ${ }^{3}$ For the sake of simplicity all other costs of the dominant firm are set equal to zero

${ }^{4}$ Further assumptions are: small country case, domestic and imported goods are homogenous
} 


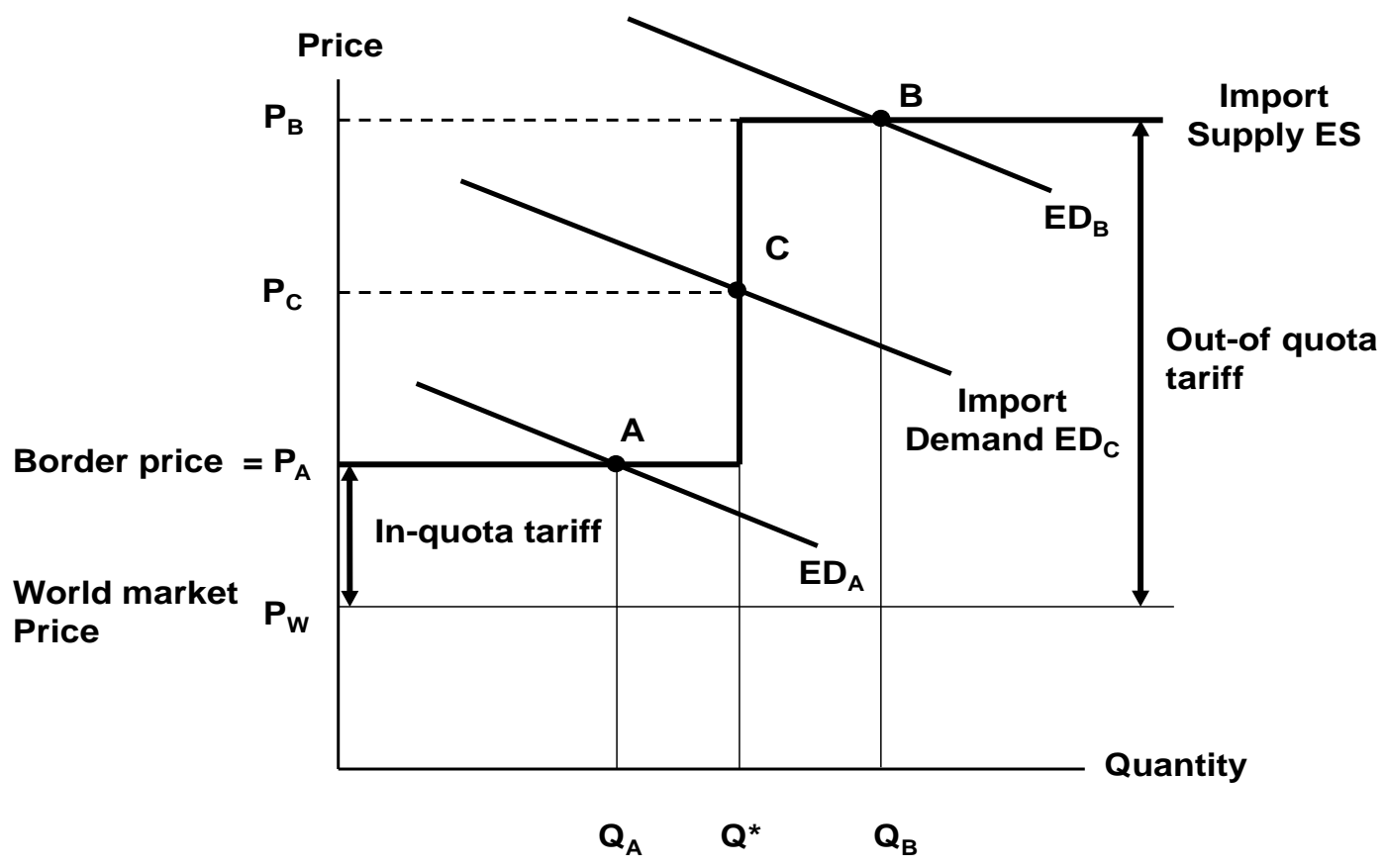

Figure 1 Tariff-rate quotas: Different cases of quota fill

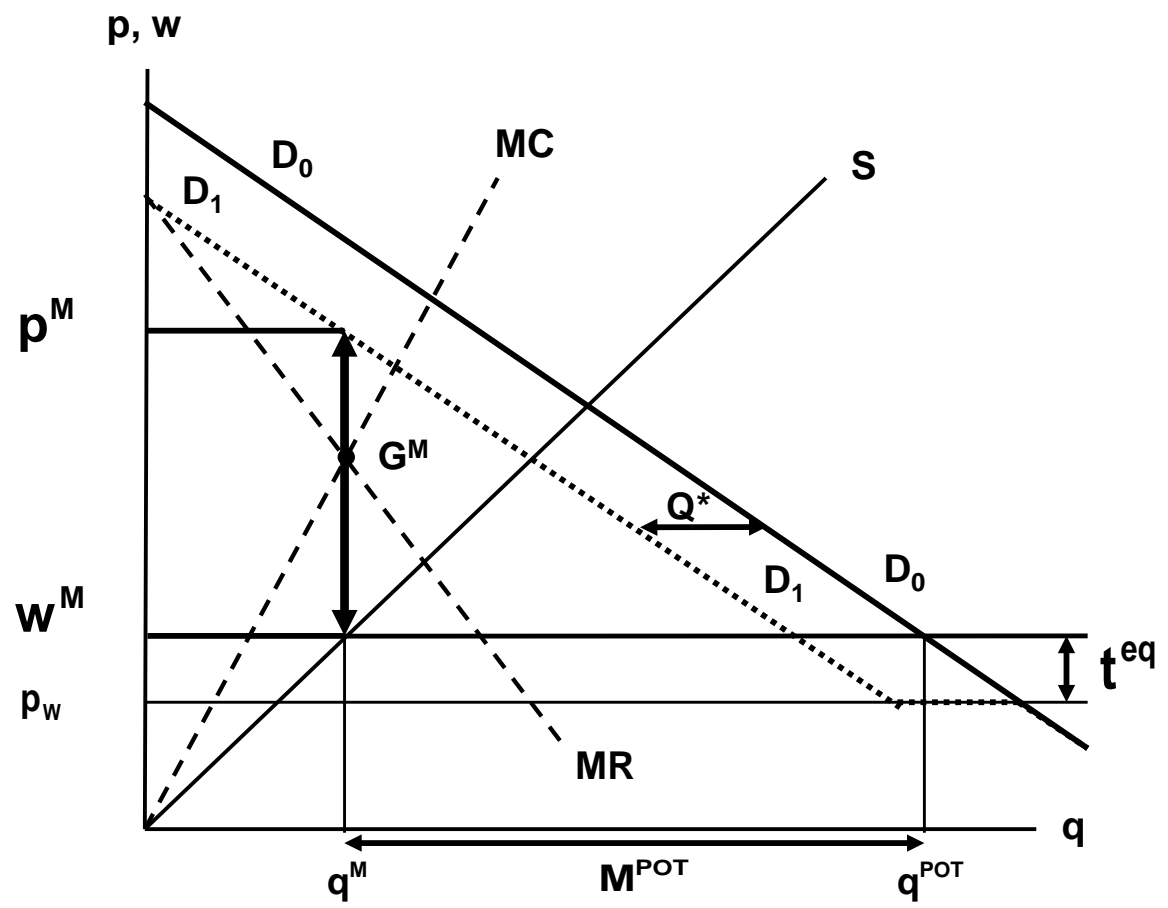

Figure 2 Market access: Comparing tariffs and quotas under imperfect competition

The assumption of a monopoly/monopsony represents the 'worst case' and it is clear that the reality is characterised by less extreme forms of imperfect competition. The consequence is that the wedge between the farm and consumer price is smaller and trade is less distorted. In the case of a competitive market, the price wedge disappears; tariffs and quotas have equivalent effects. Assessing the intensity of competition and the degree of trade distortion is a matter of empirical work. 


\section{FROM TRQs TO SINGLE TARIFFS: THE ROLE OF AUCTIONS}

The problem of imperfect competition in agricultural markets and the negative impact of quota protection on market access is obvious. Hence, the question arises how TRQs can be replaced by single tariffs. The core problem of replacing TRQs with single tariffs is linked to what procedure should be used to determine the new equivalent tariffs. One of the first approaches to auction quotas was conceptualised by Bergsten et al. (1987). At that time, skepticism emerged from two sides: exporting countries feared that the new tariffs would raise the level of protection whereas importing countries worried about the opposite effect on protection. McAfee et al. (1999) analysed the relationship between equivalent tariffs and auction prices for auctions in New Zealand during the 1980s. Their results suggest that auction prices are lower than the implicit tariffs of the quotas. According to McAfee et al. (1999, p. 175), "for a policy maker who is concerned that tariffication not raises the level of protection, the results of this article suggest that auction data may offer a useful lower bound on the tariff equivalent of a quota.” In this context another concern emerges: determining equivalent tariffs by auctions will fail if the auctions are not competitive. The problem of collusion in auctions occurs especially in markets with few bidders. The most famous case of a breakdown of competition happened in the May 1991 auction of US treasury bonds. Salomon Brothers was able to acquire control over $94 \%$ of the bonds and squeezed out large amounts of money after the auction from traders who had gone short prior to the issue (Jegadeesh, 1993). Most of the research in this field focuses on auctions of an ex ante fixed supply where collusion might occur under specific conditions.

With reference to the auctions of Swiss treasury bonds, Lengwiler (1999) analysed the Swiss system of 'variable supply' where the volume of bonds is determined only after observing the bids. In a subsequent study by Heller and Lengwiler (2001), it is suggested that there is no evidence of collusion and excessive profits of some bidders. In Finland, where a similar auction system is applied as in Switzerland, Keloharju et al. (2002) came to the same result. To conclude, the experience in both of these countries suggests that the ability to collude in systems of variable supply is lower than in auctions with an ex ante fixed supply. The fact that the quantity is determined only after the bids are submitted has far reaching strategic effects; it is a potent measure against collusion. Hence, not knowing the sold quantity in advance makes it difficult to find a common strategy to manipulate the auction. In Switzerland, treasury bond auctions take place on a bimonthly basis. In these auctions, the bidders are invited to submit as many price-quantity bids as they wish. After all the bids have been submitted, the Treasury determines the cut-off price. With this price, the Treasury also decides simultaneously the quantity that is offered at the cut-off price. Figure 3 depicts the aggregate bid function of a sample treasury bond auction. The treasury typically chooses a point on the bid function where it is at its flattest, or perhaps one price tick below. The system automatically adapts the supply to the demand of the bidders. The characteristics of the system of 'variable supply' are of particular interest for the application in agricultural markets: in the case of imperfect competition it is important to use a system that resists collusion.

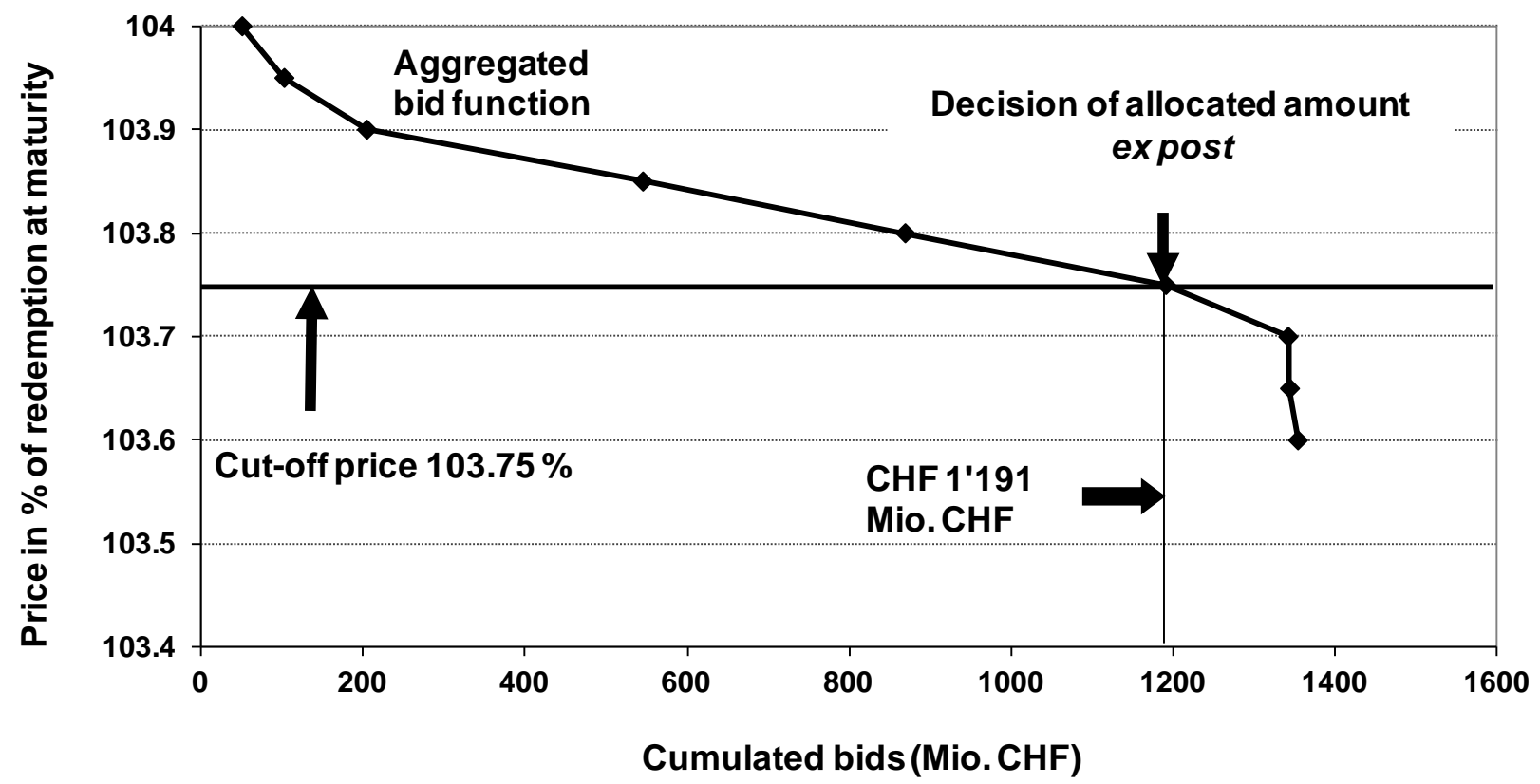

Figure 3 Auctions with ‘variable supply’: Auction of Swiss treasury bonds (Example: February 2002). Source: Swiss National Bank, Bern 


\section{AUCTIONS OF TRQS: EXPERIENCES OF SWITZERLAND}

\section{Results of auctioning TRQs}

Switzerland started auctioning TRQs for special products (white wine, dried meat products from Italy and Spain) in 1997 (Haniotis, 1998). Due to these positive experiences, the Swiss parliament in 2005 decided to apply this method of quota allocation also for all other categories of meat. For a majority of politicians, it was important that the auction system would lead to more transparency and that the state would collect the quota rents. The regulations offer two auction formats: first, the most usual auctions, the amount is disclosed to the bidders in advance. Second, auctions with 'variable supply', adopted when there are only few firms bidding, i.e., if the risk of collusion is high. Observations of past auctions have shown that there is competition among the bidders when applying the first format of auctions. Therefore, the auction with variable supply has not yet been applied (Joerin and Lengwiler 2004). However, this might change in the future in the event of growing concentration on markets.

Of particular interest in this paper, is how the results obtained from auctions in the meat market are perceived in converting TRQs into single tariffs. For the purpose of interpretation, it is helpful to use the simple TRQ model as a benchmark (Figure 1) and relate back to the case $C$ where TRQs are auctioned. In general, the Swiss auctions for meat take place monthly. They are conducted quarterly in the case of poultry and yearly for meat products (dried meat, sausages, etc.). Each bidder can submit different bids and the quotas are awarded to the highest bidder. The firms pay the price which they bid ('pay as you bid'). Since every firm registered in Switzerland is admitted to the auctions, access is simple.

Table 1 contains the results of the TRQ auctions for which the quota is binding (case $\mathrm{C}$ ). This is the regular case for meat imports (i.e., occurring in $90 \%$ of the total import quantity). The quotas are filled $100 \%$.

The Federal Office for Agriculture has the possibility, in years of high import demand, to expand the TRQs beyond the required WTO commitments. The bid rates represent the firms' willingness to pay for the right to import products at a lower in-quota tariff. ${ }^{5}$ Bids are higher for processed products than for raw products. In the case of top grade meat, such as high quality beef, bids are higher than for sausages or pork meat in carcasses. Of particular interest now, is the question how well average bids indicate the level of the equivalent tariff. Examining case $\mathrm{B}$, the domestic price is supported by the out-of quota tariff which corresponds to the equivalent tariff because there is no in-quota tariff for preferential imports from the EU. Furthermore, as it is shown in Table 2, average and lowest accepted bids ${ }^{6}$ are below the out-of quota tariffs. This observation is in line with the above mentioned study by McAfee et al. (1999) who refers to auction bids as a 'lower bound on the tariff equivalent of a quota'. Accordingly, a tariff that is determined by

\footnotetext{
${ }^{5}$ Average in-quota tariffs for meat are low:10-15\% of the border price

${ }^{6}$ The lowest accepted bid can be considered as the clearing bid
}

auctions leads to lower protection. In other words, a country which replaces TRQs by single tariffs through auctions, in so doing, has already reduced tariffs to some extent. Despite this limited empirical evidence, the case of over-quota imports generates in the long-term a reliable picture about the mechanism of auctions. Another question to be answered by future empirical research is, to reveal and determine the difference between auction prices and equivalent tariffs.

\section{Implications of auctioning TRQs}

As shown, experiences from past auctions of TRQs were positive. Hence, auctions have led to more competition in the domestic market and marketing margins have declined. Initially, opponents of such auctions - those who have been quota holders hitherto - feared that just a few firms would buy the whole lot. However, this has not been the case so far. Of course, auctions are not popular with incumbent firms because the state collects the quota rent (in 2012 ca. 200 million Swiss francs, 180 million US \$) Critics of auctioning TRQs ${ }^{7}$ strongly prefer the previous system where quotas were allocated according to domestic purchases (domestic purchase requirements system). This system was beneficial for firms which slaughter and process meat.

Table 1 Auctions of TRQs with binding quotas 20122013, quota-fill 100\%

\begin{tabular}{lrcc}
\hline Meat categories & $\begin{array}{r}\text { Quota } \\
\text { auctioned }\end{array}$ & $\begin{array}{c}\text { Bidding } \\
\text { firms }\end{array}$ & $\begin{array}{c}\text { Average } \\
\text { bids }\end{array}$ \\
\hline ton & number & CHF/kg \\
Poultry & 47,600 & 73 & 2.04 \\
Pork (carcasses) & 1,950 & 22 & 0.80 \\
Mutton & 5,535 & 29 & 2.08 \\
Horsemeat & 5,040 & 14 & 0.25 \\
Manufacturing beef & & & \\
(carcasses) & 8,978 & 22 & 0.43 \\
High quality beef & 4,646 & 61 & 11.82 \\
Veal & 304 & 26 & 6.89 \\
Processed ham & 72 & 28 & 7.40 \\
Dried ham (EU) & 1,100 & 77 & 8.74 \\
\hline
\end{tabular}

Notes: 1 Swiss Franc $(\mathrm{CHF}) \approx 0.90$ US \$

Source: Federal Office for Agriculture, Bern

Hence, the pressure from those firms on members of the parliament became recently so intense that for beef, veal and lamb 50\% of the TRQs are again allocated according to domestic purchases 2015. This is a classic example of rent-seeking behaviour which is described by Krueger (1974, p. 291) in her seminal paper as "..the welfare loss associated with quantitative restrictions is unequivocally greater than the loss from the tariff equivalent of those quantitative restrictions.” Among scientists in this field, there is great consensus that a rent-seeking behaviour can ${ }^{7}$ Schweizerischer Fleischfachverband SFF, (butchers and meat
processors) 
only be restricted through auctions. Therefore, TRQs should be allocated through auctions and all other methods of quota administration should be eliminated (De Gorter and Hranaiova, 2004).

Table 2 Auctions of a TRQ with out-of quota imports; quota-fill above $100 \%$

\begin{tabular}{|c|c|c|c|}
\hline $\begin{array}{l}\text { Dried ham from EU } \\
\text { Parma \& Spanish ham }\end{array}$ & Units & 2007-09 & 2010-12 \\
\hline In-quota imports & ton & 1,100 & 1,100 \\
\hline Out-of quota imports & ton & 624 & 1,129 \\
\hline Quota-fill & $\%$ & 157 & 203 \\
\hline $\begin{array}{l}\text { In-quota tariff } \\
\text { (preferential quota } \\
\text { for EU) }\end{array}$ & $\begin{array}{c}\mathrm{CHF} / 100 \\
\mathrm{~kg}\end{array}$ & 0 & 0 \\
\hline Out-of quota tariff & $\begin{array}{c}\mathrm{CHF} / 100 \\
\mathrm{~kg}\end{array}$ & 935 & 935 \\
\hline $\begin{array}{l}\text { Average accepted } \\
\text { bids }\end{array}$ & $\mathrm{CHF} / \mathrm{kg}$ & 7.83 & 8.34 \\
\hline $\begin{array}{l}\text { Lowest accepted } \\
\text { bids }\end{array}$ & $\mathrm{CHF} / \mathrm{kg}$ & 7.60 & 8.25 \\
\hline $\begin{array}{l}\text { Average accepted bids } \\
\text { in \% of out-of quota } \\
\text { tariff }\end{array}$ & $\%$ & 83.7 & 89.6 \\
\hline $\begin{array}{l}\text { Lowest accepted bids } \\
\text { in \% of out-of quota } \\
\text { tariff }\end{array}$ & $\%$ & 81.3 & 88.2 \\
\hline Bidding firms & number & 73 & 81 \\
\hline
\end{tabular}

\section{CONCLUSIONS}

Market access in the WTO is highly fragmented due to the two-tier tariff structure of TRQs. Converting TRQs into single tariffs would contribute to more coherence.

Converting TRQs into tariffs under perfect competition Based on the proven GATT/WTO principles, this conversion should take place in two steps: first, conversion of quotas and other non-tariff barriers to tariffs and then reduction of those tariffs gradually over time. This tariff reduction would generate improvements on market access. In the Doha Round it was intended to lower out-of quota tariffs and trigger a smooth phasingout of TRQs. This approach, however, still encounters difficulties whenever the out-of quota tariffs are very high ('water in the tariffs'). In order to convert TRQs into tariffs, equivalent tariffs are needed. In this regard, auctions can help to determine the level of the new tariffs. Auctions are the only way to elicit from quota holders their willingness to pay for imports. Once the per unit willingness to pay is known, the out-of quota tariff can be reduced to the level of the in-quota tariff plus the per unit auction payment which subsequently helps to establish the equivalent single tariff with the same level of protection. The above empirical evidence shows that auction prices are below the equivalent tariffs minus the in-quota tariffs. Therefore, a country which replaces
TRQs by single tariffs through auctions may reduce tariffs to some extent.

\section{The non-equivalence of tariffs and quotas under imperfect competition}

Based on Bhagwati's theorem of the non-equivalence of tariffs and quotas, the analysis of the impact of imperfect competition on market access leads to the following conclusion: whenever imperfect competition occurs, the change from TRQs to single tariffs improves market access even if farm prices are held constant. The higher the degree of imperfect competition, the larger the gain of market access when TRQs are replaced by single tariffs. Finally, it is important that auctions are competitive and collusion among bidders can be prevented. The 'variable supply' auction format resists collusion and the anti-collusive mechanism ensures competitive auctions in the event of high buyer's concentration.

\section{Rent-seeking: main obstacle for reforms of the TRQ regulations}

TRQs generate quota rents; therefore, holders of quotas want methods of allocation which secure them those rents in the long-term. However, this rent-seeking behaviour can only be restricted through auctions. Thus, TRQs should be allocated through auctions. All other methods contain incentives for rent-seeking and should be eliminated. The objective is to push for greater transparency and efficiency in the allocation of TRQs.

\section{REFERENCES}

ABBOTT, P. (2002). Tariff-rate quotas: failed market access instruments? European Review of Agricultural Economics, 29(1), 109-130. doi: 10.1093/erae/29.1.109.

ABBOTT, P. - PAARLBERG, P. (1998). Tariff rate quotas: structural and stability impacts in growing markets. Agricultural Economics, 19, 257-267. doi: 10.1016/S0169-5150(98)00040-1.

BERGSTEN, C. F. - KIMBERLY A. E. - SCHOTT, J.J. - TAKACS, W.E. (1987). Auction quotas and United States trade policy, Institute for International Economics, Washington, D.C.

BHAGWATI, J.N. (1965). On the equivalence of tariffs and quotas. In: Baldwin, R.E. et al. (eds.), Trade growth and the balance of payments, Chicago.

BOUGHNER, D.S. - DE GORTER, H. - SHELDON, I.M. (2000). The Economics of Two-Tier Tariff-Rate Import Quotas in Agriculture. Agricultural and Resource Economic Review, 29(1), 58-69.

DE GORTER, H. - HRANAIOVA, J. (2004). Quota Administration Methods: Economics and Effects with Trade Liberalization, in: Agriculture and the WTO, Worldbank, Washington, DC, 95-118

HANIOTIS, T. (1998). Auctions as a Trade Policy Instrument. In: Cottier et al. (eds.), State Trading in the Twenty-First Century, University of Michigan Press.

HELLER, D. - LENGWILER, Y. (2001). Should the treasury price-discriminate? A procedure for computing hypothetical bid functions. Journal of Institutional and 
Theoretical Economics, 157, 413-429. doi: 10.1628/0932456013621279.

HELPMAN, E. - KRUGMAN, P.R. (1992). Trade policy and market structure. MIT Press Cambridge, MA.

JEGADESH, N. 1993. Treasury auctions bids and the salomon squeeze. Journal of Finance, 48, 1403-1419. doi: 10.1111/j.1540-6261.1993.tb04759.x.

JOERIN, R. - LENGWILER, Y. (2004). Learning from financial markets: Auctioning tariff-rate quotas in agricultural trade. Swiss Journal of Economics and Statistics, 140(4), 521-541.

KELOHARJU, M. - NYBORG, K.G. - RYDQUIST, K. (2002). Strategic behavior and underpricing in uniform price auctions. Evidence from Finnish treasury auctions, Available at:

http://finance.aalto.fi/en/people/keloharju/strategic beha vior_in_uniform_auctions.pdf

KRUEGER, A.O. (1974). The Political Economy of the Rent-Seeking Society. The American Economic Review, 64(3), 291-303.
LENGWILER, Y. (1999). The multiple unit auction with variable supply. Economic Theory, 14, 373-392. doi: 10.1007/s001990050299.

McAFEE, P.R. - TAKACS, W. - VINCENT, D.R. (1999). Tariffying auctions. RAND Journal of Economics, 30, 158-179.

SKULLY, D. (2001). Economics of tariff-rate quota administration. TB-1893 Economic Research Service, USDA. Washington, D.C.

SMITH, A., (1811). An Inquiry into the nature and Causes of the Wealth of Nations, VI ${ }^{\text {th }}$ edition, Hartford.

WTO, (2001). Market access: Unfinished business, PostUruguay Round inventory and issues, Special Studies No. 6. Available at:

http://www.wto.org/english/res_e/booksp_e/special_stud y 6 e.pdf 